\title{
From Illness as Culture to Caregiving as Moral Experience
}

\section{Citation}

Kleinman, Arthur. 2013. From illness as culture to caregiving as moral experience. New England Journal of Medicine 368: 1376-1377.

\section{Published Version}

doi:10.1056/NEJMp1300678

\section{Permanent link}

http://nrs.harvard.edu/urn-3:HUL.InstRepos:10612560

\section{Terms of Use}

This article was downloaded from Harvard University's DASH repository, and is made available under the terms and conditions applicable to Open Access Policy Articles, as set forth at http:// nrs.harvard.edu/urn-3:HUL.InstRepos:dash.current.terms-of-use\#OAP

\section{Share Your Story}

The Harvard community has made this article openly available.

Please share how this access benefits you. Submit a story.

Accessibility 
Filename: "From Illness as Culture to Caregiving as Moral-Experience-submission-NEJMrevised-Jan-10-2013.docx"

From Illness as Culture to Caregiving as Moral Experience

Arthur Kleinman

Harvard University

Looking back over a career of forty years of publishing on how medical education and clinical practice can improve the quality of care by attending more closely to experiences of illness and caregiving, I am ambivalent now about the application of ideas long associated with me concerning suffering and caregiving as cultural practices. In the early 1970s, at a time of rapid growth of high technology, reductionism, and bureaucracy in medicine, there was rising anxiety that clilnicians were failing to treat their patients as individuals who possessed a richly human background and social context for their lives and disorders. I began publishing articles and books out of my clinical work as a consultation-liaison psychiatrist and as a cross-cultural researcher, particularly among Chinese, on how physicians' narrow focus on diagnosis and treatment of disease led them to miss or intentionally exclude the centrality of the patient's experience. I presented the patient and family's anxious and burdensome experience of illness 
and the clinician's intense quest for diagnosing and treating disease as two substantially different kinds of things. (1) While the former was a struggle to bear, interpret and respond to symptoms; the latter was an application of a particular medical system's classification of disease entities and an enactment of prototypical treatment interventions. I called for renewed attention to the patient's lived experience of symptoms, and did so by developing this distinction between illness and disease. By using eight questions to elicit lay explanatory models, the clinician could, I reasoned, understand the illness experience and therewith provide care as well as cure. (2)

Those candid questions - What do you call your problem? What do you think is its cause? How does it affect your body? What do you most fear about it and the treatment, etc.were meant to open conversations that would place the illness narrative squarely in the patientdoctor relationship, converting a somewhat one-sided exchange (this was after all the 1970s) into a humanly richer, more egalitarian one. The distinctive explanatory models of patients and physicians represented cultural orientations of the society, the profession, and the institution that authorized a certain kind of clinical reality which took on a life of its own for patients and doctors, depending on their different cultural and social backgrounds. That clinical reality would shape the treatment and the evaluation of the outcome.

Largely because there were hardly any practicable alternatives, this clinical methodology became widely taught, especially to model how to deliver effective, culturally informed care to ethnic and immigrant minorities.(3) But by the 1990s, I had become increasingly uncomfortable with the way the illness/disease distinction was being used. Eliciting the explanatory model, I came sadly to realize, had often become a conversation stopper in a consultation, a mechanical 
task that assumed that dynamic meanings could be fixed as a single, unchanging, material thing in the patient's record. On clinical rounds which I conducted with medical residents at Harvard hospitals, and in many other teaching hospitals, trainees presented cases in which the explanatory model took on the status of the $\mathrm{CBC}$ and electrolytes, as if it were also a material substance. What was meant to humanize care by providing greater space for lay voices and practices appeared to be doing just the opposite. It unintentionally reduced complex, vivid lives into limiting and biased cognitive stereotypes. To make matters worse, certain aficionados fetishized the illness narratives per se as symbols and stories, divorcing meaning from economic, emotional and relational context of the lived experience of suffering; and emphasizing storytelling and interpretive practices over the actual experience of illness. I was praised for a method, moreover, that seemed to be making culture relevant only to laypersons, as if professionals did not possess culturally patterned beliefs and practices of their own. That method also got caught up in a cultural competence movement that reified esoteric cultural beliefs and ethnic stereotypes. (3) That was not my point. Separating illness from disease also carried the danger of splitting physiology from subjectivity and interpersonal relations, which was untenable within the biosocial framework I wanted to advance.

At about this time, my wife developed early-onset Alzheimer's Disease and I got taken up in the everyday reality of being her primary caregiver. That fraught experience was transformative; it emphasized for me the primacy of illness as experience, yet made the illness/disease distinction as a cognitive divide seem shallow and inadequate. Indeed it clarified the moral processes central to caregiving. $(4,5)$ There were real things at stake for us. What mattered most—our work, our family, our lives together, our fears and aspirations—-became 
central to the giving and receiving of care. And caregiving, as I was learning from doing, was not only triage and tinkering with medication, but about being taken up in the mundane, burdensome but also meaning-infused practices of assisting with activities of daily living — bathing, toileting, feeding, ambulating — as much as protecting, supporting, and just being there. It was mundane practices that created and sustained meaning, not the other way around. The things at stake were powerfully emotional and moral. They were not just ours alone, but influenced our clinical relationships. In turn, we recognized that what mattered most to clinicians-again in emotional and moral, not just cognitive terms--was not necessarily the same as what we had at stake. Those contrasting stakes in living came to define our journey.

Nor was the local moral world of lived values - the moral experience of illness and caregiving — at all adequately mapped by ethicists' concerns with either high level principles or the ideal virtues of the practitioner. It was a messy mix of emotions, values, and relationships that was divided and in conflict both within and without. Illness and caregiving as moral experience turned on processes of reciprocal exchange. Patient and caregiver (lay and professional) reciprocated affirmation, acknowledgement, emotion and presence (i.e., meanings) as much as they exchanged information. $(4,5)$

Looking at medicine this way convinced me even further that medical schools and hospitals are structured in such a way as to become obstacles to actual caregiving. How to revivify caregiving in medicine became the issue. Teaching about the illness experience is still important. Yet, it is the moral-emotional core of that experience that deserves greater primacy. As does the social suffering that affects all of us, but especially those most marginalized who are 
already injured by poverty, isolation, and other structural violences. Another orienting issue is the lived relationship between patient (often family too) and clinician whether physician, nurse, physician's assistant or other health professional. Here the anthropological model of exchange based in reciprocity is again useful; it offers a counter to the infiltration of the market model into even the most intimate parts of health care. The anthropological perspective suggests that care is closer to gift exchange between individuals whose relationship to each other really matters. There is an exchange of stories and meanings but also of the raw experience of responsibility and emotional sensibility as in gift giving and receiving among intimate others. Over time caregiving changes the subjectivity of both caregiver and carereceiver. Ultimately, caregiving is about doing good for others; and doing good in the world, as earnest and naïve as it may sound, is what medicine is really about. It is what draws so many to its practice, even if it is also about technology, biomedical science and markets. That moral core of medicine may seem abstract, until you see health professionals passionately struggling to be useful, compassionate, responsive and responsible while working with the indifference of bureaucratic rules, the cold counting and costing of institutional audits, and the almost impossible-to-balance personal demands on their time and concern.

The greatest challenge to the practice of medicine in our times may be how to keep caregiving central to health care. It will certainly turn on structural and economic developments, as well as technologies and therapeutic models, and yet also on the importance professionals give to the deep experience of their patients and to such enduring practices of caring as the laying on of hands, the expression of kindness, the enactment of decency, and the commitment to being 
there for those who need them. That is the simple wisdom both for the art of living and the art of medical practice that emerges from one career of 40 years of rethinking and reliving this subject.

\section{$\underline{\text { References Cited }}$}

1. Kleinman, Arthur. "Medicine's symbolic reality: A central problem in the philosophy of medicine". Inquiry. 16:206-213. 1973

2. Kleinman, Arthur. The Illness Narratives. New York: Basic Books, 1988.

3. Kleinman, A., L. Eisenberg, and B. Good: “Culture, illness and care: Clinical lessons from anthropological and cross-cultural research”. Annals of Internal Med. 88:251-258, 1978.

4. Kleinman, Arthur. What Really Matters: Living a Moral Life Amidst Uncertainty and Danger. New York: Oxford University Press, 2006.

5. Kleinman, Arthur. "Caregiving as Moral Experience" The Lancet. 380:1550-1551, November 3,2012 